Ana FRITZHAND

UDK: 37.017:17: [364-43

Original research paper

\title{
MORAL DEVELOPMENT, BIOETHICS AND THEIR RELATIONSHIP IN MORAL DECISION-MAKING IN HELPING PROFESSIONS
}

\begin{abstract}
Moral development begins early in life and has its most notable progress $d u$ ring childhood and adolescence. It represents an important domain of developmental and moral psychology while interacting with other close scientific domains, such as bioethics. On its part, bioethics is specifically concerned (but not limited to) with moral principles and decisions in the context of medical practice, policy, and research. Research shows that the formal and informal bioethics education is significantly related to moral development of children and adolescents, since they influence the process of acquiring moral values, shaping one's identity and system of beliefs, as well as stimulating development of moral reasoning. Other valuable examples can be found in the process of moral decision making of professionals from so-called "helping professions" (ex. physicians, psychologists, dentists, etc.), where the transformation of moral thinking into moral behaviour becomes obvious almost on daily bases. Since abstract moral thinking proved not to be the best explanation of individual's moral behaviour, "intermediate concepts" were developed. This paper discusses the need and the importance of continuous usage of knowledge that both moral development and bioethics provide, in order to better understand the mechanisms lying in the process of making real-life moral decisions.
\end{abstract}

Keywords: MORAL DEVELOPMENT, BIOETHICS, MORAL DECISION MAKING, HELPING PROFESSIONS

\section{Introduction}

The moral psychology, in general, with moral development specifically, and bioethics are scientific disciplines that often interact. Bioethics is generally defined as the ethics of medical and biological research, while broadly understood, it could be presented as an "ethics of living". Bioethics could be described as the application of ethical rules and principles mostly in medical practice. According to the theoretical classification, it belongs to normative, i.e. applied ethics, along with medical, ecological, journalistic ethics, etc. (Donev, 2018).

Some of the questions that bioethics most often try to answer are, for example, what is the right thing to do and what is the best way to do it? 
Who is responsible, to whom and for what? What is the appropriate response to a particular moral dilemma given the context in which it occurs? On the basis of which moral reasons are the concrete claims made? etc. In its essence, it is interdisciplinary and uses the knowledge of philosophy, history, psychology, sociology, law, theology, and so on. It is in this sense that moral psychology and bioethics overlap in different areas and themes.

In moral psychology, even today, persists the goal of overcoming the gap between moral knowledge and moral behaviour. This is so, because the practice shows that the moral behaviour of an individual in everyday situations is not always in line with his/her moral knowledge. Hence, only knowing what is morally good and right, or analysing individual's moral judgment in relation to abstract moral dilemmas, is not enough to explain ones moral behaviour. This is especially evident in medical practice where confronting real-life moral dilemmas and the necessity of making moral decisions on which the moral actions of healthcare workers will be based, emerges on a daily basis.

More recent research in the field of moral psychology, complemented by neuroscience research, shows that people judge differently when faced with abstract and concrete moral dilemmas (especially dilemmas that they personally live(d) or are experiencing them emotionally). It has been confirmed that different brain areas are activated in the second type of dilemmas, which contributes to the differences in the quality of moral judgments and moral decisions. Because of this, the bioethics and the issues it discusses about, can provide useful guidance for a better understanding of the mechanisms that underlie the relation between moral knowledge and moral behaviour.

\section{Moral development and bioethics - concepts and characteristics}

Moral development includes thoughts, feelings, and behaviours that relate to standards of what is good and what is bad. It is an important domain of developmental and moral psychology. It has an intrapersonal dimension (the basic values and the individual's self) and an interpersonal dimension (a focus on how the individual should act in interactions with other people). The intrapersonal dimension regulates the activities of the individual when he/she is not involved in social interaction, while the interpersonal dimension regulates its social interactions and the way he/she resolves conflicts (Santrock, 2007).

Moral development begins early in life and marks the most significant progress in childhood and adolescence. The research (e.g., Damon, 1980, 1988, according to Turiel, 2006) of children's concepts of sharing and distribution of material goods shows that there is a developmental progression of moral judgments, that is, even very small children are to some extent 
adapted to sharing. Thus, for example, at the age of two they wait in line to play with toys and show that they can share food or candies.

On its part, bioethics is particularly interested (but not limited to) about moral principles and decisions in the context of medical practice, policy and research. In this context, bioethics deals with ethical issues that arise from the relations between life sciences, biotechnology, medicine, politics, law and philosophy. Bioethics also includes the study of the most common questions about the values that appear in primary health care and other branches of medicine. Rapid technological development, the creation of new drugs, new biomedical procedures, scientific achievements in agriculture, and so on, undoubtedly have a number of benefits in terms of increasing the quality of life of people. But, on the other hand, many innovations open a number of ethical issues and dilemmas about their long-term benefits and harms to the health and quality of life of the world's population.

The theory suggests that bioethics represents a joint, reflective examination of ethical issues in health, health science and health policy, but also in psychology, law, veterinary science and many other scientific disciplines and areas. Bioethics takes place in the media, academia, classrooms, laboratories, offices etc. It includes not only professionals, but also scientists, politicians, and the general public. Bioethics, in addition to revising traditional ethical issues, raises new questions about old problems. It deals with issues of basic human values, such as the rights to life and health, the correctness or error of certain decisions in medicine, and the responsibility of society for the life and health of humans and animals. These questions are not only relevant to medical sciences, but also to psychological, veterinarian and legal sciences. Hence, it seems that the field where knowledge from moral development and bioethics best interacts and gives most positive effect can be found precisely in helping professions.

According to McCormick (2013), in the bioethics, there are four basic principles that set the framework for moral reasoning. They include the nonmaleficience (i.e. avoidance of deliberately causing damage); justice (righteousness); beneficence (where more concrete thinking is about taking positive steps to help others); and autonomy (in terms of respecting the right of individuals to make decisions independently and being informed prior to any participation). Decisions involving bioethical issues are carried on a daily basis in a variety of situations, such as the physician-patient relationship, euthanasia issues, surrogacy, cloning, death penalty, abortion, biomedical experiments, donation of organs, animals' rights, the allocation of limited resources, and complex issues that relate to the essence and meaning of human life. 
Development of consistency between moral knowledge, moral self-concept, and moral behaviour

Developmentally speaking, with age increases the consistency between moral judgments and the choice of procedures in situations where the individual faces a real-life moral dilemma. Cognitive consistency is an endeavour to avoid contradictions between moral reasoning and procedures by explaining or seeking excuses. Consistency of procedures avoids moral contradiction by regulating them in a manner consistent with obligations and responsibility. Elderly individuals whose choices of procedures are more consistent with their obligations and responsibilities toward other individuals show greater certainty in the moral correctness of their own actions, as can be seen from the way they give their explanations (according to Keller \& Edelstein, 1993). This is accompanied by professional experience, which is an important factor in building the professional and moral integrity of the individual.

The connection between moral knowledge and moral behaviour is manifested in situations where the individual faces a real-life moral dilemma related to which he/she should make a moral decision on how to act. Evidence of this can be found in the research of Krebs and associates (Carpendale \& Krebs, 1995, according to Haviv \& Leman, 2002; Krebs, Denton \& Wark, 1997; Wark \& Krebs, according to Haviv \& Leman, 2002) as well as in Haviv \& Leman (2002). The results of their studies confirm that people do not use the same forms of moral reasoning when facing real-life moral dilemmas that they personally experienced, as when considering abstract, philosophical types of moral dilemmas. Depending on the moral perspective they take, they can give different answers. Cognitive processes that are activated in situations where a decision needs to be taken on how to act in relation to one's own self, are significantly different from those that are activated when choosing procedures in hypothetical moral dilemmas.

\section{Relationship between moral development and bioethics during moral de- cision-making in helping professions}

In everyday life, it is well known that people do not always behave in correspondence with their acquired value system. This means that in situations when they know what is good and what is bad, they sometimes choose to act differently and even quite the opposite of the adopted norms of moral and proper behaviour. From previous research it is concluded that individuals who are more mature in moral understanding and moral functioning are more consistent in their moral beliefs and actions. The type of education and profession are also significantly related to which values will be perceived as important and will therefore be placed more centrally in one's moral self- 
concept. This is shown in the theory, but also by a series of empirical findings (e.g. Fritzhand, 2013; Fritzhand, 2007). Many authors (e.g. Brabeck, 1995, according to Pejović-Milovančević, 2001) highlight that moral thinking and moral behaviour are interconnected and that moral thinking is an important guide to moral behaviour. However, this connection is not perfect and causes many uncertain and controversial results. Namely, both empirical findings and practice show that abstract moral thinking (as defined and described by Kohlberg) does not give the best explanation for the moral behaviour of an individual who is confronted with a real-life moral dilemma.

Trying to explain how the individual translates moral thinking into moral behaviour, Neo-Kohlbergians (Bebeau, 2002; Rest, Narvaez, Bebeau \& Thoma, 1999) develop "intermediate concepts". Its basic characteristic is that they describe a level of analysis that is located between Kohlberg's general schemes and specific ethical codes that point to certain rights and prohibitions. Their introduction to the theory of moral development is a consequence of the knowledge that an individual can well acquaint with abstract moral patterns, but lack proper understanding of specific moral terms relating to daily moral functioning (Strike, 1983; according to Thoma, Hestevold, Sargent, \& Crowson, 2005).

Among these intermediate concepts belong honesty, fairness, thoughtfulness, tolerance, self-discipline, courage, responsibility, and many others. They are grounded in specific professional contexts, known as "helping professions" (e.g. psychology, medicine, social work, dentistry, law, etc.). These concepts relate to the ability of the individual to identify activities and to explain the reasons and its ethical characteristics (Thoma, Hestevold, Sargent, \& Crowson, 2005). Accordingly, the abstract moral thinking directs the thinking within the framework of the principles. The intermediate concepts direct the thinking within the framework of behaviour. The ethical codes, in turn, direct the behaviour by emphasizing what is allowed and what is not, without giving the reasons and explanations of the prohibitions (Bebeau, 2002; Bebeau \& Rest 1999; Rest, Narvaez, Bebeau \& Thoma, 1999).

In terms of moral reasoning and moral decision-making, each moral situation is assessed by assessing its structure, orientation, and content. The structure implies a certain social position appropriate to the attained level of moral development of the individual. Orientation implies a moral type, since it is about analysing the impact of moral thinking on activity and actions. The content, in turn, implies universal values (according to Pejović-Milovančević, 2001). It is here that the array of questions that arise in practice comes to the fore, and, as previously mentioned, to which bioethics tries to give an answer. The questions about what is the right thing to do in a concrete situation that is perceived as a real-life moral dilemma, or who is responsible and for whom, are just one part of the many with whom those working in the helping professions face almost on daily bases. In doing so, the choice and fi- 
nal decision of the individual will depend on the achieved level of moral development (in the context of his/her stage of moral reasoning, the level of his/her moral sensitivity, the maturity of his/her moral emotions, the complexity of his/her moral self-concept, the level of his/her moral motivation, and the development of his/her moral character), but also from the context, professional experience, adopted specific theoretical knowledge, developed practical skills and a range of other relevant aspects that participate in moral decision-making.

\section{Conclusion}

The importance of the dialectical linkage between moral psychology and bioethics in the field of assisted care professions is enormous given the large number of aspects that are clearly present in the challenge of interaction and application the knowledge of these two scientific disciplines. The complexity of the tasks of these professionals, by itself, emphasizes the need for greater representation of bioethics in the curricula of professional studies, in research and in the development of useful practices and policies. In doing so, the practice of an interdisciplinary approach is of crucial importan$\mathrm{ce}$, given the fact that the person is the focus of the stated disciplines.

Many studies have reported data on the positive impact of the inclusion of bioethics in the curricula in mentioned professions, especially when it comes to medicine and dentistry (e.g. Bebeau, 2002; Bebeau \& Monson, 2008; Bebeau, Rest, \& Narvaez, 1999; Bebeau \& Thoma, 1998; 1999). Bebeau \& Thoma (1999) point out that within the ethical education of future health professionals, ethics courses are most often organized around intermediate concepts such as professional autonomy, competence, confidentiality, truthfulness, moral integrity, and so on. On the other hand, in ethical education intended for other professions, emphasis is placed on intermediate concepts such as rule of law, duty, consistency, intellectual property, collegiality, and the like. These authors communicate research results to individuals from different professions. According to them, monitoring of ethical courses reinforces the connection between several aspects of moral functioning. In addition, in elderly it is found a strong connection between the choice of procedures and explanations of the choice made. Such findings point to a clear connection between moral thinking and moral character, which manifests itself in moral decision-making and in the moral behaviour of the professional.

Knowing the nature of the helping professions and the challenges that these professionals face on a daily basis, it is necessary to increase awareness of what the future professionals are looking at different stages of their development. This involves improving knowledge through learning from the experience of older and more experienced colleagues. At the same time, it involves building character and competence. Throughout this process, the 
development and maintenance of personal, moral and professional integrity are equally important. In other words, a "good" professional is someone whose goals, values, thoughts and actions are in harmony, someone who accepts a place in the system of shared responsibilities and shared knowledge. In this context, these individuals, perhaps more than any other professionals, should always bear in mind that they serve the society, that is, to all people, not just those who can afford health, psychological or legal services. On this path, by practicing moral and bioethical principles throughout their work, they are at the same time straightened up before a moral challenge to become the best version of themselves. 


\section{References}

Bebeau, M. J. (2002). The Defining Issues Test and the Four Component Model: contributions to professional education. Journal of Moral Education, 31, 3, 271-295.

Bebeau, M. J., \& Monson, V. E. (2008). Guided by Theory, Grounded in Evidence: A Way Forward for Professional Ethics Education. Bo: Nucci, J., \& Narvaez, D. (Eds.), Handbook on Moral and Character Education, 557-582, Mahwah, NJ: Erlbaum Associates.

Bebeau, M., Rest, J., \& Narvaez, D. (1999). Beyond the Promise: A Perspective on research in Moral Education. Educational Researcher, 28, 4, 18-26.

Bebeau, M. J., \& Thoma, S. J. (1998). Designing and Testing a Measure of Intermediate Level Ethical Concepts. Paper presented at the Annual Meeting of the American Educational Research Association. San Diego, CA.

Bebeau, M. J., \& Thoma, S. J. (1999). "Intermediate" Concepts and the Connection to Moral Education. Educational Psychology Review, 11, 4, 343360.

Донев, Д. (2018). Вовед во етиката. Скопје: УКИМ.

Fritzhand, A. (2013). Moral Thinking and Moral Self-concept in Adolescence: Results from the Study on Adolescents in the Republic of Macedonia. ISBN 978-3-639-51916-7 Germany: Scholars Press.

Фрицханд, А. (2007). Вредности, вредносни ориентации, морални ставови и модели за идентификација во различни возрасни групи. Необјавен магистерски труд. Скопје: Филозофски факултет.

Hardy, S. A., \& Carlo, G. (2005). Identity as a Source of Moral Motivation. Human Development, 48, 232-256.

Hart, D. (2005). Adding Identity to the Moral Domain. Human Development, 48, 257-261.

Haviv, S., \& Leman, P. J. (2002). Moral Decision-making in Real Life: factors affecting moral orientation and behavior justification. Journal of Moral Education, 31, 2, 121-140.

Keller, M., \& Edelstein, W. (1993). The Development of the Moral Self from Childhood to Adolescence. Bo: Noam, G.G., \& Wren, T.E. (Eds.). The Moral Self, 310-336, MIT Press, USA.

Krebs, D. L., Denton, K., \& Wark, G. (1997). The forms and functions of reallife moral descision making. Journal of Moral Education, 26, 2, 131-145.

McCormick, T. (2013). Principles of Bioetics. ETHICS IN MEDICINE, University of Washington School of Medicine (прочитано на 3.05.2019 од https://depts.washington.edu/bioethx/tools/princpl.html) 
Pejović-Milovančević, M. (2001). Poremećaj ponašanja dece i omladine - moralni i psihopatološki faktori. Beograd: Zadužbina Andrejević.

Rest, J., Narvaez, D., Bebeau, M., \& Thoma, S. (1999). A Neo-Kohlbergian Approach: The DIT and Schema Theory. Educational Psychology Review, 11, 4, 291-324.

Santrock, J. W. (2007). Adolescence. Mc Graw-Hill, USA.

Thoma, S. J., Hestevold, N., Sargent, J. \& Crowson, D. (2005). Describing and testing a contextualized measure of adolescent moral thinking. (текстот е добиен во дична комуникација со првиот автор во март, 2008 година).

Turiel, E. (2006). The Development of Morality. Bo: Eisenberg, N. (Vol. Ed.). Handbook of Child Development. Vol. Three: Social, Emotional and Personality Development, pp. 789-858. John Wiley and Sons. 